\title{
BONDRES DANGDANG KETEKUNG SEBAGAI MEDIA KOMUNIKASI PENDIDIKAN
}

\author{
Niluh Wiwik Eka Putri ${ }^{1}$ \\ STAHN Mpu Kuturan Singaraja
}

Abstract

Keywords

\section{PENDAHULUAN}

Pada era digital membuat semua orang bisa dengan mudah mengakses informasi yang tak hanya cepat, tetapi juga besar. Hal ini juga mengubah cara kita mengonsumsi hingga membagikan informasi itu. Saat ini, sebagian besar warga ingin berbagi apa pun kepada siapa pun, baik momen bahagia atau sedih. Mulai dari menunjukkan hasil masakan, foto-foto diving, cincin pertunangan, hingga mata sembabnya karena tersenggol kegagalan. Semua di-share meretas batas waktu dan jarak. Menariknya, dari kebiasaan berbagi ini menghasilkan

${ }^{1}$ wiwikekaputri@gmail.com 
suatu kolaborasi antar manusia untuk membawa peradaban ke tingkat lebih tinggi (Nurudin, 2017:1).

Media baru dengan kemampuan konvergensi yang tinggi telah melahirkan dilema legislasi yang spesifik. Perkembangan teknologi inilah yang kemudian 'memaksa' para pengambil kebijakan di berbagai belahan dunia untuk mengambil sikap mengenai hal ini. Karakter media baru harus dihadapi dengan kebijakan yang komprehensif. Hanya dengan itulah situasi "critical iunture' dapat dihindarkan. Sebuah titik kritis dimana keputusan penting harus segera diambil agar masyarakat tidak dikorbankan (Wahyuni, 2020).

Teknologi yang berkembang dari

masa ke masa juga menunjukkan perkembangan peradaban umat manusia di setiap zamannya. Teknologi dibuat untuk mempermudah aktivitas manusia. Teknologi telah memaksa manusia untuk menemukan banyak hal. Misalnya, penemuan satelit telah memunculkan teknologi yang memanfaatkannya seperti telepon, internet, dan kemudahan dalam mendapatkan informasi melalui media massa.

Seiring dengan perkembangan teknologi komunikasi, masyarakat Bali masih tetap melaksanakan tradisi upacara dan kesenian umat Hindu di Bali. Dalam pelaksanaan upacara ritual umat Hindu selalu memerlukan seni pertunjukkan. Seni pertunjukan Bali dibagi secara umum ke dalam tiga kategori, yakni tari wali, tari bebali, dan tari balih-balihan. Jenis tari wali adalah yang difungsikan untuk kepentingan upacara, sedang jenis tari yang difungsikan untuk menyertai sebuah upacara adat disebut sebagai tari bebali. Seni pertunjukan yang lepas dari kaitan upacara dan mengutamakan fungsi hiburannya dikategorikan sebagai seni balih-balihan. Tidak tertutup kemungkinan bahwa seni pertunjukan dipentaskan sebagai jenis bebali juga digarap untuk tujuan kesenian hiburan atau balih-balihan.

Salah satu seni Balih-balihan adalah bondres. Bondres sering dipentaskan dalam kegiatan ritual Di Bali. Bondres dijadikan sebagai media komunikasi yang bisa mengedukasi masyarakat dengan kemasan yang unik seperti menampilkan tokoh-tokoh yang lucu, serta humor-humor yang segar. Pelaksanaan tradisi upacara dan kesenian bagi umat Hindu Bali adalah sesuatu yang inheren.

$\begin{array}{llr}\text { Bondres } & \text { merupakan seni } \\ \text { pertunjukkan topeng yang sering }\end{array}$ menampilkan tokoh-tokoh yang lucu, dengan humor-humor yang segar. Bondres mempunyai keleluasaan untuk menampilkan gerak dan narasi dialog karena bondres tidak mempunyai pakem khusus sehingga seniman topeng bisa mengeksplor ekspresi topeng bondres itu sendiri (Dibia, 1998:11).

Tarian ini adalah selingan dari pertunjukan seni topeng Bali yang terkenal pada masa kerajaan Gelgel pemerintahan Raja Waturenggong. Kemudian berkembang dan terbentuk menjadi seni baru. Dari selingan pertunjukkan seni topeng kemudian muncul seni lawak khas Bali atau yang lebih dikenal dengan Bebondresan. Bondres mengalami perkembangan menjadi pertunjukan tersendiri yang lebih mengutamakan lawakan atau banyolan khas bondres dari pada alur cerita itu sendiri. (Asmarandani Diah 2011:36).

Keberadaan seni pertunjukkan Bondres mulai dikenal di Bali pada tahun 1990. Ketika itu, pertunjukan topeng acap kali menampilkan tokoh serta humor yang lucu nan segar. Adapun tokoh topeng terdiri dari 
Topeng pengelembar (tokoh tua dan tokoh keras). Penasar kelihan yang tua, penasar cenikan yang lebih muda. Ratu (dalem dan patih). Bondres (tokoh rakyat). Lakon cerita biasanya bersumber dari cerita sejarah atau yang biasanya disebut babad. Lakon merupakan seseorang yang memainkan peran sebagai comedian atau pelawak diatas panggung dalam seni pertunjukkan Bondres.

Pertunjukkan Bondres pertama kali dipentaskan oleh I Ketut Kodi, I Nyoman Catra, dan I Gusti Lanang Ardika. Ketiga seniman ini adalah dosen ISI (Institut Seni Indonesia) Denpasar. Mereka kerap tampil melakukan pertunjukkan dalam berbagai acara, baik untuk kepentingan upacara keagamaan, maupun pementasan untuk misimisi kesenian ke berbagai negara Asia, Eropa maupun Amerika. Pementasan Bondres ini diiringi gamelan geguntangan yang dibawakan oleh sanggar Seni Makaradhwaja di bawah pimpinan Dr. Swasthi Widjaja Bandem (Dibia, 1998:11-12).

Kodi dalam Tesisnya yang berjudul "Topeng Bondres dalam Perubahan masyarakat Bali", (2006:33) mengatakan bondres memiliki konotasi dengan kata gores, mores, dan koras-kores, yakni serumpun istilah yang berpotensi kotor, campuran, sembrono, dan acak-acakan. Selanjutnya dikatakan bondres sama dengan bodo dan lucu, karena melalui bondres seniman dan penonton bersukaria dengan berbagai macam kebodohan, skandal, kelucuan, serta hal-hal negatif lainnya.

Pandangan Kodi, didukung Suanda (2014) dalam Tesisnya berjudul "Babondresan arja Acah Canging", dengan hasil penelitiannya adalah babondresan arja Acah Canging adalah bentuk babondresan paarjaan yaitu sajian humor yang dilakukan oleh hampir setiap pemainnya, dengan menggunakan elemen bahasa (dialog, monolog), tata busana, alur cerita, riasan (tata rias), gerak tari, musik pengiring, property.

Bondres dan babondresan (bentuk jamak dari bondres, Kodi 2006:33) adalah sajian seni pertunjukan yang lebih mengutamakan lucu/humor dalam penampilannya. Hal inilah yang menyebabkan bondres lebih cepat populer dibandingkan dengan seni pertunjukan lainnya. Selain lelucon yang dibawakan, peran teknologi informasi dan komonikasi sangat mendukung kesuksesan pada setiap pertunjukan bondres.

Komunikasi dalam pendidikan merupakan unsur yang sangat penting kedudukannya. Bahkan ia sangat besar peranannya dalam menentukan keberhasilan pendidikan yang bersangkutan. Orang sering berkata bahwa tinggi-rendahnya suatu capaian mutu Pendidikan dipengaruhi pula oleh faktor komunikasi ini, khususnya komunikasi Pendidikan (Yusup, 1990:13).

Komunikasi pendidikan dapat diartikan sebagai komunikasi yang terjadi dalam suasana pendidikan. Dengan demikian, komunikasi pendidikan adalah proses perjalanan pesan atau informasi yang merambah bidang atau peristiwa-peristiwa pendidikan. Disini komunikasi tidak lagi bebas atau netral, tetapi dikendalikan dan dikondisikan untuk tujuan-tujuan Pendidikan. Proses pembelajaran pada hakikatnya adalah proses komunikasi, penyampaian pesan dari pengantar ke penerima. Pesan yang disampaikan berupa isi atau ajaran yang dituangkan ke dalam simbol-simbol komunikasi, baik verbal (kata-kata dan tulisan) maupun non-verbal. Proses ini dinamakan encoding. Penafsiran simbolsimbol komunikasi tersebut oleh siswa 
dinamakan decoding (Ngainun Naim, 2011: 17).

Bondres erat kaitannya dengan komunikasi pendidikan, mengingat pesan yang disampaikan mengandung nilai-nilai pendidikan. Secara sederhana dapat dikatakan bahwa nilai adalah sesuatu yang menyangkut baik dan buruk, sedangkan norma adalah sesuatu yang menyangkut benar dan salah. Theodore (dalam Sabarani, 2012:179) menyatakan bahwa nilai merupakan suatu yang abstrak, dijadikan pedoman serta prinsip-prinsip umum dalam bertindak dan bertingkah laku. Keterikatan orang atau kelompok terhadap nilai dan norma relatif sangat kuat dan bahkan bersifat emosional. Oleh karena itu, nilai dan norma dapat dilihat sebagai pedoman untuk menuntun kecerdasan emosional, bertindak, dan sekaligus sebagai tujuan kehidupan manusia.

Nilai dihubungkan dengan budaya, mengutip pendapat Koentjaraningrat (1990:85) nilai budaya terdiri atas konsepsikonsepsi yang hidup dalam alam pikiran sebagian besar warga masyarakat mengenai hal-hal yang mereka anggap mulia. Sejalan dengan pandangan Koentjaraningrat, Robert Sibarani (2012:178-179) menyatakan nilai dan norma budaya merupakan konsepsi yang ada dalam alam pikiran sebagian besar komunitas tentang kebudayaan yang mereka anggap baik dan buruk. Nilai dan norma budaya bukan konsepsi pribadi, melainkan konsepsi warga komunitas; ada sistem bersama (shared system) komunitas untuk menentukan nilai dan norma pada suatu tradisi. Karakter adalah kualitas mental atau moral, kekuatan moral, nama atau reputasi. Karakter sebagai "ciri khas" yang memiliki oleh suatu benda atau individu. Ciri khas tersebut adalah asli dan mengakar pada kepribadian individu dan merupakan mesin pendorong bagaimana seseorang bertindak, bersikap, berujar, dan merespons sesuatu (Majid, 2010:11; Juanda, 2011:3).

Dalam lakon bondres masing-masing tokoh memiliki karakter tersendiri yang mencerminkan identitasnya. Seperti Gede Lusuh memiliki karakter bijak, jujur, sopan dan dewasa. Sementara Komang Repot berkarakter cuek, dan kurang sopan. Wayan Sogol mempunyai karakter lambat, gugup, dan selalu di tindas. Krisna berkarakter keras, dan egois. Lawakan-lawakan yang dibawakan berbau hal-hal yang positif, seperti halnya pemberian nasihat atau wejangan-wejangan yang bermanfaat bagi masyarakat lewat sebuah pertunjukan bebondresan. Selain itu, kelompok ini juga ikut berperan aktif dalam melestarikan seni pertunjukkan bondres. Dangdang Ketekung berperan mensosialisasikan pentingnya dunia pendidikan dalam membentuk karakter generasi muda lewat lawakan-lawakan yang mereka bawa pada saat pentas.

\section{METODE}

Metode yang digunakan adalah kualitatif dengan pendekatan fenomenologi. Fenomenologi bukanlah suatu aliran atau doktrin, namun lebih tepat disebut sebagai metode yang berangkat dari suatu gerakan mencakup berbagai doktrin yang memiliki inti umum sebagai pemersatu berbagai sistem dan pembenar atas fenomenologi.

Secara umum, penelitian ini menggunakan tiga pendekatan secara metodologis dalam fenomenologi Husserl. Pertama, reduksi eidetis, yaitu suatu tindak reduksional yang bertujuan mengungkap struktur dasar esensial (eidos) atau hakikat dari suatu fenomena asli. Kedua, reduksi fenomenologis, yaitu kelanjutan reduksi 
pertama yang ditujukan pada kesadaran subjek sebagai lapangan penghayatan (lived experience), yang meliputi esensi tradisi, kepercayaan, asumsi, aksioma, atau hukum, norma-norma dan lain-lain. Ketiga, reduksi transendental, yaitu upaya pemberian makna atas subjek transcendental sebagai sumber makna atas kesadaran kita sendiri (Calhoun, dkk., 2007: 32-42).

Melalui fenomenologi Husserl, penelitian ini dipandu dengan fenomenologi Alfred Schultz. Husserl sebagai pendahulu Schultz memberikan pikiran filosofis, selanjutnya oleh Schultz diberikan arah metode untuk mendapatkan genuinity (keaslian) nilai dan makna atas fenomenologi yang terjadi pada masyarakat.

Dalam peristiwa seni pertunjukan (teater), fenomenologi Schultz mengajak untuk menemukan kembali local wisdom (kearifan lokal) pada suatu masyarakat yang menjadi subjek atas aktivitas-aktivitas kesadarannya, baik sosial, seni, dan budaya (Jaeni, 2015:74-75). Berangkat dari metode penelitian fenomenologi yang telah disebutkan, penulis melakukan reduksi eidistis dan reduksi fenomenologis terhadap objek penelitian tentang bondres sebagai media komunikasi pendidikan.

Penelitian ini dilakukan dengan memaksimalkan observasi pada tarian bondres untuk mengungkap kesadaran subjek tentang pengalaman hidup sebagai penari bondres dalam ruang pendidikan. Bentuk pengumpulan data melalui observasi dan wawancara tersebut menjadi bagian dari cara penulis untuk memahami tindakan, ucapan, dan interaksi dalam tari bondres sebagai media komunikasi pendidikan.

Melalui metode tersebut, penulis memperoleh pengetahuan mengenai terbentuknya dunia keseharian para seniman bondres lewat kesadaran intersubjektif. Kesadaran demikian, merupakan konteks realitas yang dianggap sebagai intersubjektif, berbagi, dan bernegosiasi dalam interaksi sosial sebagai proses komunikasi dengan aktor komunikasi lainnya (dalam bondres) melalui penyesuaian diri dengan tindakan orang lain.

Penelitian dilakukan di Singaraja, Buleleng yang memiliki pembelajaran seni pertunjukan bondres. Informan penelitian ini adalah seniman bondres yang secara purposive sampling dipilih oleh penulis. Sementara analisis data dilakukan melalui reduksi eidetis dan fenomenologis. Analisis melalui reduksi eidistis, yaitu peneliti mereduksi setiap kegiatan pembelajaran bondres para seniman guna mengungkap hakikat dari pembelajaran bondres tersebut sebagai fenomena asli.

Sementara analisis reduksi fenomenologis dilakukan penulis dengan mencocokkan data observasi dan wawancara untuk mendapatkan kesadaran terhadap seni bondres sebagai lapangan penghayatan bagi para pelakunya. Seluruh kegiatan yang dilakukan penulis dituangkan dalam simpulan-simpulan sebagai rangkaian data yang orisinal dan dituliskan sebagai hasil kajian fenomenologi. Selanjutnya peneliti harus mengakhiri proses penelitian tersebut dengan menyimpulkan hasil melalui beberapa kategori bondres sebagai media komunikasi pendidikan.

\section{PEMBAHASAN}

Hasil dan pembahasan mengenai bondres sebagai media komunikasi pendidikan akan diuraikan sebagai tujuan dari tulisan ini. Pertama, penelitian menunjukkan bagaimana keterkaitan bondres dengan dunia pendidikan dan 
mengungkapkan tentang proses komunikasi seni bondres sebagai media komunikasi pendidikan.

\section{Bondres dan Pendidikan}

Pertunjukan Topeng Bondres sebagai media komunikasi pendidikan kini semakin berkembang. Adegannya yang lucu ditambah dengan pesan mendidik membuat Topeng Bondres menjadi media yang mampu membuat masyarakat terdedukasi sekaligus terhibur.

Pagelaran topeng Bondres biasanya diawali dengan humor, lalu dilanjutkan dengan materi yang berisi nilai pendidikan, ajakan yang berisikan penekanan mengenai hal-hal apa saja yang boleh dilaksanakan atau yang tidak boleh dilaksanakan melalui dialog kepada penonton.

Setiap seniman memiliki gaya masing-masing ketika menyampaikan pesanpesan kepada penonton. Pesan pendidikan yang disampaikan bisa bersifat religius, sosial, pendidikan dan sebagainya.

Ari Udayana, seorang penari Bondres Dangdang Ketekung dari Desa Kalibukbuk Lovina sangat aktif dalam pentas tari bondres. Arik sudah pentas keliling bersama timnya, baik di Buleleng ataupun di luar Buleleng. Dalam setiap pentasnya, ia selalu menyelipkan nilai-nilai pendidikan agama Hindu dalam balutan humor khas Buleleng.

Biasanya ada beberapa ajakan yang saya sampaikan kepada penonton. Seperti ajakan untuk menggunakan kata-kata yang positif agar tidak membuat orang lain tersinggung dan tersakiti. Seperti jangan memukul, lebih baik merangkul, jangan menghina lebih baik membina, jangan menyerang lebih baik menyayangi, jangan menginjak, lebih baik mengajak, jangan jadi kelinci lebih baik jadi bikul, artinya jangan membenci lebih baik merangkul. Tujuan dari kata-kata positif tersebut agar tercipta hidup yang harmonis dan damai. Tentu di dalam ajakan tersebut terdapat unsur-unsur komunikasi pendidikan yang sesuai dengan adat dan istiadat Bali.

Masyarakat pengguna seni sering kali menggunakan pertunjukan Topeng Bondres sebagai alat propaganda yang berisi suatu ajakan di dalamnya. Hal tersebut dilakukan karena kelebihan dari pada Topeng Bondres adalah memiliki akses komunikasi langsung dengan berbagai tingkat sosial masyarakat dengan memanfaatkan kebebasan yang membuat kesenian ini banyak dilirik serta dimanfaatkan sebagai media yang handal oleh pemerintah dan swasta dalam mewujudkan visi dan misi suatu lembaga.

Pertunjukan Topeng Bondres sebagaimana halnya seni pertunjukan rakyat lainnya di Bali, sangat sarat dengan muatan pesan yang bersifat pendidikan. Pesan-pesan ini bisa yang berkaitan dengan ajaran Agama Hindu, etika moral dan bisa pula mengenai pandangan hidup. Kesenian dalam kehidupan manusia dapat diperlakukan sesuai dengan konteksnya, sehingga kesenian akan mendapatkan makna sesuai dengan konteks tersebut.

Pagelaran Topeng Bondres memainkan beberapa peranan sosiokultural yang cukup signifikan baik dalam tataran makna, pesan maupun amanat. Makna dan peranan yang dimainkan Topeng Bondres dalam kontak perubahan masyarakat Bali meliputi makna edukatif/pencerahan, yang disampaikan melalui monolog, dialog, gerak, nyanyian dan lakon dalam suatu pertunjukan.

Disamping itu juga sebagai wadah penyaluran aktivitas seni, penyalur kritikkritik dan komentar sosial serta sebagai perekat yang disampaikan dalam bentuk WIDYA DUTA | VOL. 16, NO. 1 |2021 
ungkapan spontanitas. Dalam pertunjukan Topeng Bondres nilai-nilai pendidikan (Agama Hindu) bisa disampaikan lewat lakon (lelampahan), nyanyian (gending) dan lawakan (bebanyolan) dengan bentuk berdialog langsung.

Dramatari tari topeng bondres sebagai salah satu produk budaya masyarakat Bali yang memiliki keunikan tersendiri. Pertunjukan dramatari topeng dalam pelaksanaan sebuah upacara keagamaan adalah sebagai bagian dari upacara, sedangkan pertunjukannya sendiri bisa digunakan sebagai media komunikasi pendidikan dan sekaligus merupakan hiburan bagi partisipan yang datang ke pura.

Dalam perkembangannya, bondres atau bebondresan mengacu pada kegiatan lelucon yang bertujuan menghibur masyarakat Bali. Para pelakon memerankan bermacam-macam karakter, yang pada dasarnya dipertunjukkan oleh satu atau lebih orang dengan mendemonstrasikan kepiawiannya. Aktor harus dapat menarik perhatian penontonnya dengan mengganti setiap karakter yang dibawakan dalam perselangan waktu yang singkat dan menghidupkan karakter yang dibawakan.

Hingga saat ini kesenian drama tari bondres masih terus dilestarikan oleh masyarakat Bali. Seperti halnya pemerintah kabupaten Buleleng yang menggelar lomba bondres pada acara Pekan Apresiasi Seni (PAS). Tujuan diadakannya lomba ini ialah untuk memperkenalkan dan melestarikan kesenian bondres mulai dari tingkat desa sampai ke masyarakat luas.

"Dalam rangka HUT Kota Singaraja ke-412 Pemerintah Kabupaten Buleleng menggelar Lomba Bondres di hari keempat Pekan Apresiasi Seni (PAS) yang bertempat di Lapangan Bhuana Patra pada hari Senin (11/4). Kegiatan yang memperebutkan total hadiah sepuluh juta rupiah serta uang pembinaan sebesar lima juta rupiah kepada setiap peserta ini diikuti oleh sembilan peserta yang berasal dari sekeha topeng yang ada di masing-masing kecamatan di Kabupaten Buleleng. Adapun sekehe topeng tersebut adalah sekehe topeng Dharma Duta (Kecamatan Busungbiu). Jiwaksara (Kubutambahan), Teja Santhi (Tejakula), Paguyuban Topeng Dharma Budaya Desa Pakraman Sangket (Sukasada), Galih Galuh (Banjar), Dharma Swara (Buleleng), Sanggar Seni Wisnu Murti (Sawan), Manik Segara (Gerokgak), Sanggar Samgraha Budaya (Seririt). Lomba Bondres tersebut dinilai oleh tiga orang juri yang berasal dari unsur Listibya, ketiga juri tersebut adalah Nyoman Suma Argawa, Gede Begug Mahardika, dan I Made Ngurah Sadika. Adapun kriteria penilaian para juri meliputi ide/gagasan dan isi pesan yang disampaikan, kemampuan dan kematangan teknik penyajian, kualitas vokal, bahasa dan struktur bahasa serta kualitas humor, alur/plot penyajian, kreativitas serta keharmonisan penyajian. setelah dari proses penilaian tersebut akhirnya juara pertama diraih oleh sekehe bondres Teja Santhi duta Kecamatan Tejakula dan untuk juara kedua serta ketiga diraih oleh sekehe bondres Dharma Swara dan Wisnu Murti Duta Kecamatan Buleleng dan Sawan. (bulelengkab.go.id)

Lomba bondres yang diselenggarakan oleh Pemerintah Kabupaten Buleleng secara tidak langsung menarik minat masyarakat untuk terus melestarikan kesenian bondres. Dalam pementasan bondres biasanya 
menampilkan "interpreter" dengan figurfigur rakyat jelata. Pemunculannya menjanjikan kelucuan-kelucuan. Penekanan ekspresi tokoh-tokoh ini bertumpu pada topeng-topengnya yang lucu dan karikatural. Beberapa topeng bondres ada yang memiliki bentuk setengah terbuka, diantaranya pada bagian dagu, pipi, hidung, kening, tergantung dari karakter yang ingin ditonjolkan.

Secara mendasar topeng adalah benda yang mewakili bentuk atau rupa wajah manusia atau mahkluk sebagai 'potret' (Mack, 1996:9) definisi ini hamper sama dengan definisi "mask is personal, and its function was to define the category of the person potrayed" (Hamlyn, 1992:151). Seni topeng juga mengandung makna transformasi personal dan transformasi sosial seperti mengubah penampilan, bersembunyi, bayangan atau cadar yang menutupi kepribadian manusia yang sesungguhnya (Teoti Heraty, 1984:10).

Topeng dapat diartikulasikan pada manusia atau 'aku-wajah' dan atau kepala manusia, transformasi tentang kepala atau wajah sebagai simbol kekuatan paling besar dari daya hidup manusia, namun dapat juga sebagai transformasi dari kepala atau wajah binatang garuda, kuda, singa atau ular/naga yang dipercaya mempunyai kekuatan magis/ supranatural; dalam budaya-kehidupan bangsa Yunani ditemukan kata 'persona' atau 'prosophon' yang artinya menutupi wajah atau menyembunyikan wajah sehingga dapat diartikan sebagai topeng dan persona yang mempunyai muatan konsep 'Human Dignity' (hakikat manusia) manusia yang mempunyai martabat, atau manusia yang mempunyai nilai-nilai kemanusiaan, nilai-nilai sosial (manusia sebagai mahluk sosial) seperti moral/etika, berpikir, dan akal-budi yang cenderung sebagai nilai yang abstrak.
Menurut Edy Sedyawati topeng merupakan ekspresi simbolis untuk menyalurkan kesan/tanggapan atas alam beserta sifat-sifatnya, atas konsep budaya tertentu melalui bentukan visual yang bergaya grostek (seram, dahsyat, menakutkan/seram dan menjijikan/lucu). Dan semua bentuk, ekspresi, dan keberadaan topeng merupakan cara pengungkapan dan pemahamnan terhadap kehidupan manusia dan eksistensi manusia dengan alam (Suseno, 1991: 196).

Uraian tentang topeng Bondres sebagai bagian dari dramatari topeng tradisional Bali yang terkait dengan kegiatan ritual keagamaan, upacara adat Hindu-Bali adalah juga sebuah kegiatan budaya, kesenian dan tari, dimana seluruh kegiatankegiatan tersebut berikut tatanan lain juga saling terkait melekat secara turun temurun dalam kehidupan masyarakat Hindu-Bali.

Seperti halnya dengan pemikiran Koentjaraningrat budaya-kesenian-tari yang ada dalam masyarakat Hindu Bali dapat dibagi menjadi tiga wujud yaitu mentifak yang berkaitan dengan pemikiran dan falsafah dasar kebudayaan, sosiofak berkaitan dengan perilaku dan merupakan penerapan nyata dari mentifak dalam kehidupan sebuah masyarakat/komunitas, selanjutnya artefak merupakan hasil nyatakarya-bentuk dari sebuah kebudayaan yang berbentuk tarian, musik tradisional, lagu dan karya seni tradisional (cinderamata). Semua wujud kebudayaan akan saling terkait dalam kesatuan budaya yang akan terus berjalan dan hidup dengan cara diwariskan, hidup dari generasi ke generasi, khususnya dalam masyarakat Hindu Bali.

Topeng Bondres sebagai salah satu tokoh dalam dramatari, bukan sekedar benda yang menggambarkan physiognomi atau

WIDYA DUTA | VOL. 16, NO. 1 |2021 
ekspresi topeng atau wajah manusia yang ekstrim, topeng Bondres pada mulanya merupakan salah satu tokoh dalam dramatari topeng Bali yang selalu hadir dalam kegiatankegiatan upacara adat, ritual keagamaan dalam kehidupan masyarakat Hindu Bali.

Bondres dalam bahasa Bali dapat diartikan rakyat atau dapat pula diartikan sebagai punakawan atau sebagai abdi dalem, dalam sistem tatanan kemasyarakatan Bali (topeng) Bondres merupakan personifikasi dari kasta yang paling bawah yang disebut dengan Sudra (atau Jaba untuk non Bali), artinya dalam sebuah dramatari topeng Bali juga terdapat tokoh lain yang sesuai dengan tatanan kasta yang ada seperti tokoh topeng Keras dan topeng Tua, Penasar (Kelihan yang lebih tua, Cenikan yang lebih muda), Patih (prime minister) dan Ratu (Dalem atau Raja) serta Bondres (rakyat).

Dalam membawakan lakon/ babad/cerita babad dalam dramatari topeng Bali para penari menggunakan topeng bungkulan (menutup seluruh muka penari) dan topeng sibakan (topeng separuh) yang menutup sebagian muka dari dahi hingga rahang atas termasuk yang hanya menutup bagian dahi dan hidung; dengan demikian yang menggunakan topeng bungkulan (topeng penuh) tidak dapat melakukan dialog (wicara) dan yang menggunakan topeng sibakan dapat berdialog dalam bahasa Kawi dan Bali. Hampir keseluruhan tokoh Bondres menggunakan topeng yang sibakan atau topeng separuh sehingga dapat melakukan dialog (topeng wicara), namun kelebihan dari Bondres adalah dapat melakukan dialog diluar pakem/wanda dari pementasan sebuah dramatari, artinya dapat berdialog dengan menggunakan bahasa popular seperti bahasa sehari-hari, bahkan bahasa asing selain bahasa Bali, kadang dalam bentuk lawakan/banyolan, sehingga penonton atau audience dapat mengerti semua dialog atau maksud/isi dari suatu upacara diadakan. (tokoh Bondres mempunyai tugas untuk menterjemahkan bahasa Bali atau Kawi yang diucapkan Pedande/ pendeta atau kalimatkalimat dari Penasar, bahkan menterjemahkan gesture dari Raja-Ratu / Dalem).

Dalam suatu dramatari tradisional Bali tokoh Bondres ada beberapa tokoh dan masing-masing mempunyai ekspresi tersendiri, ada tokoh Bondres yang bernama Pasek Bandesa atau Bondres Tua, Bondres Perempuan Nyoman Semariani, Nyai Sekar, Bondres Cungih bondres cacat pada bagian hidung dan bibir, Bondres Kete yang tidak memiliki hidung dan bibir, Bondres Pemabok, Bondres Ngantuk dan lainnya tergantung koleksi seniman. Secara keseluruhan topeng Bondres sekalipun pekerjaannya mbanyol mereka tetap menggunakan pakaian lengkap dramatari topeng sama dengan tokoh lain hanya saja ditambah dengan asesori-asesori tertentu.

Bondres Dangdang Ketekung masih tetap eksis ditengah perkembangan teknologi komunikasi saat ini. Dalam beberapa event Dangdang Ketekung di undang untuk mengisi acara seperti di SMK 2 Nusa Dua Grokgak, Hut Kota Singaraja, dan sebagainya. Dilihat dari cara pembelajaran yang dilakukan pada kelompok bondres Dangdang Ketekung ini dapat digolongkan ke sistem pewarisan cantrik karena pewarisan ilmu yang diterapkan melalui ajakan. Selain itu Dangdang Ketekung juga sering ngayah di pura-pura yang ada di Kabupaten Buleleng.

Pemberian contoh pada proses belajarnya, serta memiliki kelebihan tersendiri pada setiap orangnya. Pada awalnya dikarenakan karena terjalin 
keakraban di antara pemain sehingga timbul sebuah ide untuk membuat sebuah kelompok bondres yang saat itu cuma beranggotakan tiga orang penari yaitu Reka, Luken, dan Komang Repot yang merupakan pelatih dari kelompok ini, akhirnya tercetuslah nama Dangdang Ketekung. Proses atau cara belajar dari anggota Dangdang Ketekung ini dilakukan dengan diberikannya contoh lakon yang dimainkan oleh pengajarnya setelah itu anggota diberikan kesempatan untuk berlatih serta menyesuaikan lakon yang diberikan dengan kepribadian mereka masing-masing agar memudahkan memerankannya pada saat pentas.

Dangdang Ketekung ini awalnya terbentuk melalui komunitas yang bernama soblek. Kemudian beralih nama menjadi Dangdang Ketekung, Dangdang berarti wadah dan ketekung artinya kepompong. Jadi Dangdang Ketekung berarti wadah atau tempat yang melalui proses perkembangan dari kecil hingga menjadi besar. Mereka juga memanfaatkan media sosial seperti facebook, Instagram, dan youtube agar lebih dikenal oleh masyarakat luas khususnya generasi muda.

\section{Bondres Dangdang Ketekung Sebagai Media Komunikasi Pendidikan}

Komunikasi Pendidikan dapat diartikan sebagai komunikasi yang terjadi dalam suasana Pendidikan. Dengan demikian, komunikasi Pendidikan adalah proses perjalanan pesan atau informasi yang merambah bidang atau peristiwa-peristiwa Pendidikan. Disini komunikasi tidak lagi bebas atau netral, tetapi dikendalikan dan dikondisikan untuk tujuan-tujuan Pendidikan. Proses pembelajaran pada hakikatnya adalah proses komunikasi, penyampaian pesan dari pengantar ke penerima. Pesan yang disampaikan berupa isi/ajaran yang dituangkan ke dalam simbol-simbol komunikasi, baik verbal (kata-kata dan tulisan) maupun nonverbal. Proses ini dinamakan encoding. Penafsiran simbolsimbol komunikasi tersebut oleh siswa dinamakan decoding.

Dalam dunia Pendidikan, komunikasi menjadi kunci yang cukup determinan dalam mencapai tujuan. Seorang guru, betapa pun pandai dan luas pengetahuannya, kalau tidak mampu mengomunikasikan pikiran, pengetahuan, dan wawasannya, tentu tidak akan mampu memberikan transformasi pengetahuannya kepada para siswanya. Gugusan pengetahuannya hanya menjadi kekayaan diri yang tidak tersalur kepada para siswanya. Oleh karena itu, kemampuan komunikasi dalam dunia Pendidikan sangat penting artinya.

Berkaitan dengan signifikasi komunikasi Pendidikan, sebagaimana dituturkan Yusuf, terdapat beberapa hal yang dianggap penting. Pertama, kegagalan komunikasi Pendidikan atau instruksional yang sering terjadi di lapangan, tampaknya proses Pendidikan dan instruksional yang dalam pandangan psikologi kognitis disebut sebagai struktur kognisi seseorang, baik dalam kedudukannya sebagai komunikator maupun dalam perannya sebagai komunikan, tidak berfungsi sebagaimana mestinya.

Kedua, para guru dan praktisi komunikasi instruksional di lapangan sering tidak memahami beragam pendekatan dalam pelaksanaan instruksionalnya. Mereka sering tidak paham akan dasar-dasar teori belajar yang sudah teruji secara ilmiah bisa meningkatkan prestasi belajar sasaran jika digunakan secara tepat. Ketiga, aspek-aspek psikologis, seperti kemampuan dan/atau kapasitas kecerdasan yang dimiliki oleh

WIDYA DUTA | VOL. 16, NO. 1 |2021 
manusia, minat, bakat, motivasi, perhatian, sensasi, persepsi, ingatan, retensi, faktor lupa, kemampuan mentransfer, dan verpikir kognitif, sering tidak mendapat perhatian dalam kegiatan komunikasi Pendidikan, terutama oleh komunikator instruksional. Hal ini bisa menyebabkan berkurangnya optimasi proses komunikasi yang sedang berlangsung. Akibatnya, hasil proses komunikasinya pun menjadi tidak optimal, bahkan tidak sesuai dengan tujuan-tujuan Pendidikan dan tujuan instruksional yang telah ditetapkan, alias gagal.

Keempat, model komunikasi terbuka tampaknya lebih cocok untuk diterapkan dalam kegiatan Pendidikan, termasuk di dalamnya kegiatan instruksional karena sifatnya yang lebih dapat memberi peluang untuk saling mengontrol kesalahankesalahan yang mungkin ada, baik bagi komunikator sendiri maupun bagi komunikan belajar (sasarna). Sifat model komunikasi terbuka ini antara lain adalah dialogis, persuasive, dan edukatif. Kelima, dalam pandangan psikologis belajar kognitif, proses komunikasi bisa berjalan dengan lancer dan mempunyai arti yang luas jika antara informasi yang satu dan informasi yang lain terdapat kaitan atau rangkaian yang terikat dalam struktur kognitif seseorang. Karenanya, belajar adalah proses perubahan dalam struktur kognitif orang yang bersangkutan.

Keenam, komunikator Pendidikan atau komunikator instruksional jika ingin menjalankan fungsinya dengan sebaikbaiknya, diisyaratkan menggunakan logika berpikir yang sama dengan logika berpikir yang dimiliki oleh pihak komunikan belajar (sasaran). Dengan begitu, pelaksanaan instruksionalnya akan berhasil dengan baik. Namun, yang sering terjadi di lapangan justru tidak disadari oleh praktisi komunikasi di lapangan. Mereka banyak melakukan kegiatan instruksionalnya dengan spontan dan kebiasaannya tanpa memerhatikan faktor dominan pihak sasaran.

Ketujuh, para komunikator praktisi lapangan sering tidak memanfaatkan sumber-sumber belajar yang tersedia di pusat sumber belajar bersama yang dikelola oleh perpustakaan. Padahal, kita tahu bahwa hasil belajar sasaran selama ini bukanlah semata-mata karena hasil sampaian informasi dari guru atau dosennya, melainkan banyak menyerap hasil dan bahan belajar dari sumber-sumber belajar lain, seperti teman diskusi, orang lain yang sepaham, media, buku, computer, dan internet, yang semuanya banyak tersedia di perpustakaan. Bahkan, dengan adanya fasilitas computer dan internet untuk tujuan Pendidikan dan instruksional, para guru, dosen, dan juga siswa serta mahasiswa bisa lebih langsung dan nyata dalam memahami situasi dan kondisi contoh kasus yang disampaikan oleh media canggih ini.

Kedelapan, pemanfaatan multimedia instruksional. Para komunikator Pendidikan dan instruksional belum banyak yang memanfaatkan multimedia untuk tujuan instruksional. Kesembilan, pendekatan information literacy dan media literacy dalam setiap praktik instruksional. Siapapun yang bertindak sebagai komunikator instruksional di zaman sekarang, sangat relevan jika menggunakan beragam pendekatan yang melibatkan keterlibatan dan pengetahuan teknologi informasi dan media.

Topeng bondres Dangdang Ketekung tidak bisa lepas dari beberapa poin-poin di atas. Komunikasi pendidikan yang diterapkan dalam pementasan topeng bondres diharapkan mampu memberi kontribusi 
penting dalam pemahaman dan praktik interaksi serta tindakan seluruh individu yang terlibat. Dalam pementasannya, mereka paham akan model-model komunikasi seperti dialogis, persuasif dan edukatif. Sehingga ajaran-ajaran pendidikan dapat tersampaikan kepada khalayak. Salah satunya tentang ajaran Tri Kaya Parisudha, Tri Kita Karana, dan topik-topik yang tengah trend saat ini.

\section{PENUTUP}

Berdasarkan pemaparan terkait bondres Dangdang Ketekung sebagai media komunikasi pendidikan maka dapat di simpulkan bahwa Bondres Dangdang Ketekung masih eksis saat ini, hal tersebut dapat dibuktikan dengan seringnya mereka mengisi acara diberbagai kegiatan yang ada di Kabupaten Buleleng. Dengan masih aktif Dangdang Ketekung, menandakan jika masyarakat terhibur dengan lawakanlawakannya. Selain itu, Dangdang Ketekung juga memanfaatkan media sosial seperti facebook, Instagram, dan youtube agar lebih dikenal oleh masyarakat luas khususnya generasi muda.

Topeng bondres Dangdang Ketekung tidak bisa lepas dari beberapa poin-poin di atas. Komunikasi pendidikan yang diterapkan dalam pementasan topeng bondres diharapkan mampu memberi kontribusi penting dalam pemahaman dan praktik interaksi serta tindakan seluruh individu yang terlibat. Dalam pementasannya, mereka paham akan model-model komunikasi seperti dialogis, persuasif dan edukatif. Sehingga ajaran-ajaran pendidikan dapat tersampaikan kepada khalayak. Salah satunya tentang ajaran Tri Kaya Parisudha, Tri Kita Karana, dan topik-topik yang tengah trand saat ini.

\section{DAFTAR PUSTAKA}

Dibia, Wayan. (1998) "Topeng Pajegan" Perfoming Art-Indonesia Hertage. Jakarta:Archipelago.

Juanda, Asep. 2011. "Nilai-nilai Positif Peribahasa Sunda dalam Pendidikan Karakter Bangsa" (dalam Seminar Nasional Bahasa dan Sastra Membangun Karakter Bangsa, Nining Nur Alaini dkk., penyunting). Mataram: Kantor Bahasa Provinsi NTB.

Koentjaraningrat. 1990. Kebudayaan, Mentalitet, dan Pembangunan. Jakarta: Gramedia.

Majid, Abdul \& Dian Andayani. 2010. Pendidikan Karakter dalam Perspektif Islam. Bandung: Insan Cita Utama.

Ngainun Naim. 2011. Dasar-Dasar Komunikasi Pendidikan. Yogyakarta:ArRuzz Media

Pratyaksa, I.G.T., (2019) Strategi Komunikasi Persuasif oleh Opinion Leader dalam Implementasi Penggunaan Aksara Sastra dan Busana Adat Bali. Calathu: Jurnal Ilmu Komunikasi 1 (2), 40-48. https://journal.uc.ac.id/index.php/cal athu/article/view/1016

Pratyaksa, I.G.T., Putri, NLWE. (2020) Peranan New Media Dalam Transformasi Fungsi Komunikator Dan Fungsi Konstruksi (Dramaturgy Akun Instagram Walikota Denpasar Rai Mantra Tahun 2019). Ganaya: Jurnal Ilmu Sosial Dan Humaniora 2 (2-3), 92-103. http://jayapanguspress.penerbit.org/i ndex.php/ganaya/article/view/391/38 0

Pratyaksa, I.G.T. (2020). Peranan Perempuan Hindu Milenial Sebagai Opinion Leader Kesetaraan Gender di Era 4.0. COMMUNICARE 1 (1). 64-73. https://stahnmpukuturan.ac.id/jurnal/ WIDYA DUTA | VOL. 16, NO. 1 |2021 
index.php/communicare/article/view/ 759

Pratyaksa, I.G.T. (2020). Komik Online Sebagai Media Penyuluhan Agama Hindu Bagi Generasi Milenial. Maha Widya Duta 3 (2), 21-29. https://stahnmpukuturan.ac.id/jurnal/ index.php/duta/article/view/737

Pratyaksa, I.G.T. (2020). New Media Sebagai Sarana Penyuluhan Agama Hindu Oleh Digital Native. Danapati: Jurnal Ilmu $\begin{array}{lll}\text { Komunikasi } & 1 & \text { (1), }\end{array}$ https://jurnal.ekadanta.org/index.php /danapati/article/view/36

Pratyaksa, I.G.T. (2020). New Media Sebagai Strategi Komunikasi Online Pariwisata Untuk Mempromosikan Potensi Lokal Desa Wisata Sudaji. CULTOURE: Culture Tourism and Religion 1 (2), 198-208.

http://jurnal.stahnmpukuturan.ac.id/i ndex.php/cultoure/article/view/834

Pratyaksa, I.G.T. (2020). Bahasa Ibu Zaman Now Dalam Budaya Komunikasi Antarpribadi. Maha Widya Duta 2 (1), 36-41.

http://www.jurnal.stahnmpukuturan. ac.id/index.php/duta/article/view/46

Pratyaksa, I.G.T. (2019). Strategi Komunikasi Persuasif oleh Opinion Leader dalam Implementasi Penggunaan Aksara Sastra dan Busana Adat Bali. Calathu: Jurnal Ilmu Komunikasi 1 (2), 40-48. https://journal.uc.ac.id/index.php/cal athu/article/view/1016

Pratyaksa, I.G.T. (2019). Inter Culture Communication In The Life of The Hindu In Mojokerto. Proceeding International Seminar (ICHECY) 1 (1). 99-103.

https://stahnmpukuturan.ac.id/jurnal/ index.php/ichecy/article/download/12 $\underline{3 / 116}$

Pratyaksa, I.G.T., Putri, N.W.E (2020). Aplikasi Spoon Radio sebagai Alternatif Industri Kreatif. Jurnal Paradigma Madani 7 (2). 19-30.

http://ejurnal.uij.ac.id/index.php/PAR /article/view/925

Putri, N.W.E. (2020) Komunikasi Sosial Dalam Mensosialisasikan Penetapan Kebijakan Gubernur Bali Tentang Pembatasan Timbulan Sampah Plastik Sekali Pakai. Jurnal Nomosleca 5 (1). http://jurnal.unmer.ac.id/index.php/n /article/view/2783/1755

Putri, N.W.E. (2020) Peran Psikologi Komunikasi dalam Mengatasi Permasalahan Peserta Didik: Studi Kasus Proses Bimbingan Konseling di SMK Kesehatan Widya Dharma Bali. Calathu: Jurnal Ilmu Komunikasi 1 (1), 52-67.

https://journal.uc.ac.id/index.php/cal athu/article/view/776

Putri, N.W.E. (2020). Interaksi Simbolik dalam Proses Komunikasi Nonverbal pada Aplikasi Tiktok. Widya Duta: Jurnal Ilmiah Ilmu Agama dan Ilmu Sosial $\begin{array}{lll}\text { Budaya } & 14 & \text { (1), } 11-19 .\end{array}$ http://ejournal.ihdn.ac.id/index.php/V idyaDuta/article/view/1039

Putri, N.W.E. (2020). Perempuan Hindu Dalam Kajian Komunikasi Politik Dan Gender. COMMUNICARE 1 (1), 30-39. http://jurnal.stahnmpukuturan.ac.id/i ndex.php/communicare/article/view/ 756

Putri, N.W.E. (2020). Semiotika Pierce Pada Film Dokumenter 'Sexy Killers'. Maha Widya Duta 3 (2), 89-100. http://www.jurnal.stahnmpukuturan. ac.id/index.php/duta/article/view/745 
Putri, N.W.E. (2020). Peran Facebook Sebagai Media Komunikasi Pada Organisasi Sisya Veda Sastra. Maha Widya Duta 2 (2), 79-86. http://jurnal.stahnmpukuturan.ac.id/i ndex.php/duta/article/view/666

Putri, N.W.E. (2020). Komunikasi Pemasaran Dinas Pariwisata Kabupaten Buleleng Dalam Meningkatkan Jumlah Wisatawan Di Buleleng. Jurnal Komunikasi Profesional 3 (1). https://61.8.70.50/index.php/jkp/artic le/viewFile/1705/825

Putri, N.W.E. (2019). Non Verbal Communication Means of Providing Hindu's People (Case Study: Harassment Of Hindu Cultural Symbols By Young Hindu Generations Through Falling Stars Challenge). Proceeding International Seminar (ICHECY) 1 (1). https://stahnmpukuturan.ac.id/jurnal/ index.php/ichecy/article/viewFile/126 $\angle 119$

Putri, N.W.E. (2020). Komunikasi Persuasif Pemerintah Kabupaten Buleleng Dalam Menanggulangi Pandemi Covid19. Communicare 1 (2) 124-133. http://jurnal.stahnmpukuturan.ac.id/i ndex.php/communicare/article/view/ 939/pdf

Sabarani, Robert. 2012. Kearifan Lokal: Hakikat, Peran, dan Metode Tradisi Lisan. Jakarta: ATL.

Suyuti, Suminto A. 2012. "Pengkajian Seni Suatu Jagat Penandaan" dalam Kuswarsantyo ed., Greget Joget Ngayogyakarta, Yogyakarta: Bale Seni Condoradana.

\section{Sumber lain:}

https://bulelengkab.go.id/detail/berita/tunj ukan-eksistensi-bondres-melalui-pas.
(Diakses pada 23 April 2019, pukul 13.22).

Asmarandani, Diah. 2011. Topeng Bondres Bali: Sebuah Kajian Seni Ekresi Topeng. 